Supplement of Atmos. Chem. Phys., 22, 2891-2907, 2022

https://doi.org/10.5194/acp-22-2891-2022-supplement

(C) Author(s) 2022. CC BY 4.0 License.

(c) (1)

Atmospheric
Chemistry
and Physics

E़่ে

Supplement of

\title{
Continental-scale contributions to the global CFC-11 emission increase between 2012 and 2017
}

\section{Lei Hu et al.}

Correspondence to: Lei Hu (lei.hu@noaa.gov)

The copyright of individual parts of the supplement might differ from the article licence. 


\section{Supplementary Text. \\ Tests performed for estimating 4D CFC-11 background mole fraction fields}

We derived several background mole fraction fields for comparison. Initially, we examined the modeled 4D monthly CFC-11 mole fractions from the Whole Atmosphere Community Climate Model (WACCM). In the WACCM simulation, global mole fractions and distributions of CFC11 were initialized in the year 1980. The WACCM model was run using version 1.2.2 with interactive chemistry in the specified dynamics configuration at a resolution of $1.9^{\circ}$ latitude $\times 2.5^{\circ}$ longitude horizontal with 88 vertical levels from Earth's surface to $6 \times 10^{-6} \mathrm{hPa}$. Horizontal winds and temperatures were nudged to specified dynamics derived from the Modern Era Retrospective-analysis for Research and Applications (MERRA2). Compared to the ATom observations, these WACCM forward simulations show 2 ppt positive average biases (Fig. S3), with larger biases in the higher northern latitudes $(\sim 4 \mathrm{ppt})$. We also tried scaling this forward modelled background to reduce its latitudinal bias. For this purpose, we calculated monthly, latitude-dependent scaling factors every $30^{\circ}$ in latitude based on the ratios between the WACCM modeled average CFC-11 mole fractions below $3 \mathrm{~km}$ and the surface CFC-11 mole fractions observed by the NOAA long-term global weekly surface flask-air sampling network. This scaling allowed a reduction of latitudinal biases in the WACCM simulations (Fig. S3), although a $\sim 2 \mathrm{ppt}$ bias still exists in the equatorial region. As an alternative, we constructed an empirical 4D CFC11 mole fraction field based on NOAA observations. A 4D empirical measurement-based background field was constructed by propagating a subset of measured mole fractions of CFC-11 from the NOAA global surface and ongoing airborne flask-air sampling programs back in time along the 5000 back-trajectories for a certain time duration. This subset of observations was selected given their measured mole fractions were lower than a certain threshold in each $30^{\circ}$ in latitude $\mathrm{x} 3 \mathrm{~km}$ in altitude box. We tested a range of thresholds between the $40^{\text {th }}-80^{\text {th }}$ percentile in the HIPPO and ATom periods. We ended up selecting observations lower than the $70-80^{\text {th }}$ percentile in each box as background observations during the HIPPO period and ones lower than the $40-50^{\text {th }}$ percentile as background observations during the ATom period, so that the inversely derived global emissions in both periods were consistent with those derived from the global 3-box model with different choices of atmospheric lifetimes (Montzka et al., 2021). By propagating this subset of observations back in time, it provided a 4D field of CFC-11 mole fractions that we then averaged every $5^{\circ}$ latitude $\times 20^{\circ}$ longitude $\times 2 \mathrm{~km}$ altitude every half or one month. We tested the time duration of $10-30$ days for propagating particles along the 5000 back-trajectories and half or one month averaging time windows for estimating this empirical background. We found propagating particles back in time for 10 days with an averaging window of one month can produce a background field that best agrees with independent ATom and HIPPO observations (Figs. S3 and S4). We further added the influence of stratospheric air on high altitude CFC-11 mole fractions $(8-10 \mathrm{~km})$ in the polar regions $\left(>60^{\circ} \mathrm{N}\right.$ or $\left.>60^{\circ} \mathrm{S}\right)$ to this empirical background by considering the vertical gradients simulated by WACCM over these regions. As a result, this approach produced a background that best agreed with the ATom and HIPPO observations compared to the previous two approaches (Figs. S3 and S4). Therefore, we used the 4D background field derived from a subset of CFC-11 measurements in our final global inversion simulations. Note that, the HIPPO and ATom campaign data were intentionally excluded and used as independent assessment of the 4D background estimates at first; but they were later included in the final 4D empirical background construction, after we confirmed that the empirical approach produced the best estimate of background. 
Table S1. A list of the 23 inversion ensembles constructed for this study.

\begin{tabular}{|c|c|c|c|}
\hline \multirow{2}{*}{$\begin{array}{l}\text { Inversio } \\
\text { n ID }\end{array}$} & \multicolumn{3}{|r|}{ Inversion configurations } \\
\hline & Observations & Background & Prior emissions \\
\hline 1 & $\begin{array}{c}\text { Only flask } \\
\text { measurements }\end{array}$ & Background $1^{\mathrm{a}}$ & $\begin{array}{l}\text { Population-density-based priors with global emissions of } 67 \mathrm{Gg} \\
\qquad \mathrm{yr}^{-1} \text { for the HIPPO and ATom periods }\end{array}$ \\
\hline 2 & $\begin{array}{l}\text { Only flask } \\
\text { measurements }\end{array}$ & Background 1 & $\begin{array}{l}\text { Population-density-based priors with global emissions of } 40 \mathrm{Gg} \\
\qquad \mathrm{yr}^{-1} \text { for the HIPPO and ATom periods }\end{array}$ \\
\hline 3 & $\begin{array}{l}\text { Flask }+ \text { in situ } \\
\text { measurements }\end{array}$ & Background 1 & $\begin{array}{l}\text { Population-density-based priors with global emissions of } 67 \mathrm{Gg} \\
\qquad \mathrm{yr}^{-1} \text { for the HIPPO and ATom periods }\end{array}$ \\
\hline 4 & $\begin{array}{l}\text { Flask }+ \text { in situ } \\
\text { measurements }\end{array}$ & Background 1 & $\begin{array}{l}\text { Population-density-based priors with global emissions of } 40 \mathrm{Gg} \\
\qquad \mathrm{yr}^{-1} \text { for the HIPPO and ATom periods }\end{array}$ \\
\hline 5 & $\begin{array}{l}\text { Flask }+ \text { in situ } \\
\text { measurements }\end{array}$ & Background $2^{\mathrm{b}}$ & $\begin{array}{l}\text { Population-density-based priors with global emissions of } 67 \mathrm{Gg} \\
\qquad \mathrm{yr}^{-1} \text { for the HIPPO and ATom periods }\end{array}$ \\
\hline 6 & $\begin{array}{l}\text { Flask }+ \text { in situ } \\
\text { measurements }\end{array}$ & Background 2 & $\begin{array}{l}\text { Population-density-based priors with global emissions of } 67 \mathrm{Gg} \\
\mathrm{yr}^{-1} \text { for the HIPPO period and } 87 \mathrm{Gg} \mathrm{yr}^{-1} \text { for the ATom period. } \\
\text { The } 20 \mathrm{Gg} \mathrm{yr}^{-1} \text { increase was imposed over North America. }\end{array}$ \\
\hline 7 & $\begin{array}{l}\text { Flask }+ \text { in situ } \\
\text { measurements }\end{array}$ & Background 2 & $\begin{array}{l}\text { Population-density-based priors with global emissions of } 67 \mathrm{Gg} \\
\mathrm{yr}^{-1} \text { for the HIPPO period and } 87 \mathrm{Gg} \mathrm{yr}^{-1} \text { for the ATom period. } \\
\text { The } 20 \mathrm{Gg} \mathrm{yr}^{-1} \text { increase was imposed over South America. }\end{array}$ \\
\hline 8 & $\begin{array}{l}\text { Flask }+ \text { in situ } \\
\text { measurements }\end{array}$ & Background 2 & $\begin{array}{l}\text { Population-density-based priors with global emissions of } 67 \mathrm{Gg} \\
\mathrm{yr}^{-1} \text { for the HIPPO period and } 87 \mathrm{Gg}^{-1}{ }^{-1} \text { for the ATom period. } \\
\text { The } 20 \mathrm{Gg} \mathrm{yr}^{-1} \text { increase was imposed over Africa }\end{array}$ \\
\hline 9 & $\begin{array}{l}\text { Flask }+ \text { in situ } \\
\text { measurements }\end{array}$ & Background 2 & $\begin{array}{l}\text { Population-density-based priors with global emissions of } 67 \mathrm{Gg} \\
\mathrm{yr}^{-1} \text { for the HIPPO period and } 87 \mathrm{Gg} \mathrm{yr}^{-1} \text { for the ATom period. } \\
\text { The } 20 \mathrm{Gg} \mathrm{yr}^{-1} \text { increase was imposed over Europe. }\end{array}$ \\
\hline 10 & $\begin{array}{l}\text { Flask }+ \text { in situ } \\
\text { measurements }\end{array}$ & Background 2 & $\begin{array}{l}\text { Population-density-based priors with global emissions of } 67 \mathrm{Gg} \\
\mathrm{yr}^{-1} \text { for the HIPPO period and } 87 \mathrm{Gg}^{-1}{ }^{-1} \text { for the ATom period. } \\
\text { The } 20 \mathrm{Gg} \mathrm{yr}^{-1} \text { increase was imposed over Australia. }\end{array}$ \\
\hline 11 & $\begin{array}{l}\text { Flask }+ \text { in situ } \\
\text { measurements }\end{array}$ & Background 2 & 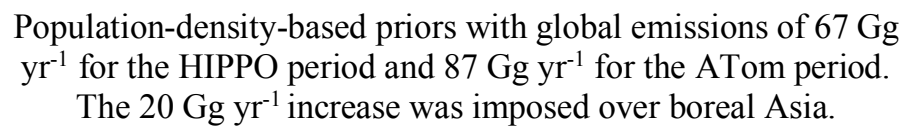 \\
\hline 12 & $\begin{array}{l}\text { Flask }+ \text { in situ } \\
\text { measurements }\end{array}$ & Background 2 & $\begin{array}{l}\text { Population-density-based priors with global emissions of } 67 \mathrm{Gg} \\
\mathrm{yr}^{-1} \text { for the HIPPO period and } 87 \mathrm{Gg} \mathrm{yr}^{-1} \text { for the ATom period. } \\
\text { The } 20 \mathrm{Gg} \mathrm{yr}^{-1} \text { increase was imposed over temperate eastern } \\
\text { Asia. }\end{array}$ \\
\hline 13 & $\begin{array}{l}\text { Flask }+ \text { in situ } \\
\text { measurements }\end{array}$ & Background 2 & $\begin{array}{l}\text { Population-density-based priors with global emissions of } 67 \mathrm{Gg} \\
\mathrm{yr}^{-1} \text { for the HIPPO period and } 87 \mathrm{Gg} \mathrm{yr}^{-1} \text { for the ATom period. } \\
\text { The } 20 \mathrm{Gg} \mathrm{yr}^{-1} \text { increase was imposed over temperate western } \\
\text { Asia. }\end{array}$ \\
\hline
\end{tabular}




\begin{tabular}{|c|c|c|c|}
\hline 14 & $\begin{array}{l}\text { Flask }+ \text { in situ } \\
\text { measurements }\end{array}$ & Background 2 & $\begin{array}{l}\text { Population-density-based priors with global emissions of } 67 \mathrm{Gg} \\
\mathrm{yr}^{-1} \text { for the HIPPO period and } 87 \mathrm{Gg} \mathrm{yr}^{-1} \text { for the ATom period. } \\
\text { The } 20 \mathrm{Gg} \mathrm{yr}^{-1} \text { increase was imposed over tropical Asia. }\end{array}$ \\
\hline 15 & $\begin{array}{l}\text { Flask }+ \text { in situ } \\
\text { measurements }\end{array}$ & Background 2 & $\begin{array}{l}\text { Population-density-based priors with global emissions of } 87 \mathrm{Gg} \\
\mathrm{yr}^{-1} \text { for the HIPPO period and } 67 \mathrm{Gg} \mathrm{yr}^{-1} \text { for the ATom period. } \\
\text { The } 20 \mathrm{Gg} \mathrm{yr}^{-1} \text { decrease was imposed over North America. }\end{array}$ \\
\hline 16 & $\begin{array}{l}\text { Flask }+ \text { in situ } \\
\text { measurements }\end{array}$ & Background 2 & $\begin{array}{l}\text { Population-density-based priors with global emissions of } 87 \mathrm{Gg} \\
\mathrm{yr}^{-1} \text { for the HIPPO period and } 67 \mathrm{Gg} \mathrm{yr}^{-1} \text { for the ATom period. } \\
\text { The } 20 \mathrm{Gg} \mathrm{yr}^{-1} \text { decrease was imposed over South America. }\end{array}$ \\
\hline 17 & $\begin{array}{l}\text { Flask }+ \text { in situ } \\
\text { measurements }\end{array}$ & Background 2 & $\begin{array}{l}\text { Population-density-based priors with global emissions of } 87 \mathrm{Gg} \\
\mathrm{yr}^{-1} \text { for the HIPPO period and } 67 \mathrm{Gg} \mathrm{yr}^{-1} \text { for the ATom period. } \\
\text { The } 20 \mathrm{Gg} \mathrm{yr}^{-1} \text { decrease was imposed over Africa. }\end{array}$ \\
\hline 18 & $\begin{array}{l}\text { Flask }+ \text { in situ } \\
\text { measurements }\end{array}$ & Background 2 & $\begin{array}{l}\text { Population-density-based priors with global emissions of } 87 \mathrm{Gg} \\
\mathrm{yr}^{-1} \text { for the HIPPO period and } 67 \mathrm{Gg} \mathrm{yr}^{-1} \text { for the ATom period. } \\
\text { The } 20 \mathrm{Gg} \mathrm{yr}^{-1} \text { decrease was imposed over Europe. }\end{array}$ \\
\hline 19 & $\begin{array}{l}\text { Flask }+ \text { in situ } \\
\text { measurements }\end{array}$ & Background 2 & $\begin{array}{l}\text { Population-density-based priors with global emissions of } 87 \mathrm{Gg} \\
\mathrm{yr}^{-1} \text { for the HIPPO period and } 67 \mathrm{Gg} \mathrm{yr}^{-1} \text { for the ATom period. } \\
\text { The } 20 \mathrm{Gg} \mathrm{yr}^{-1} \text { decrease was imposed over Australia }\end{array}$ \\
\hline 20 & $\begin{array}{l}\text { Flask }+ \text { in situ } \\
\text { measurements }\end{array}$ & Background 2 & $\begin{array}{l}\text { Population-density-based priors with global emissions of } 87 \mathrm{Gg} \\
\mathrm{yr}^{-1} \text { for the HIPPO period and } 67 \mathrm{Gg} \mathrm{yr}^{-1} \text { for the ATom period. } \\
\text { The } 20 \mathrm{Gg}_{\mathrm{yr}}^{-1} \text { decrease was imposed over boreal Asia. }\end{array}$ \\
\hline 21 & $\begin{array}{l}\text { Flask }+ \text { in situ } \\
\text { measurements }\end{array}$ & Background 2 & $\begin{array}{l}\text { Population-density-based priors with global emissions of } 87 \mathrm{Gg} \\
\mathrm{yr}^{-1} \text { for the HIPPO period and } 67 \mathrm{Gg} \mathrm{yr}^{-1} \text { for the ATom period. } \\
\text { The } 20 \mathrm{Gg} \mathrm{yr}^{-1} \text { decrease was imposed over temperate eastern } \\
\text { Asia. }\end{array}$ \\
\hline 22 & $\begin{array}{l}\text { Flask }+ \text { in situ } \\
\text { measurements }\end{array}$ & Background 2 & $\begin{array}{l}\text { Population-density-based priors with global emissions of } 87 \mathrm{Gg} \\
\mathrm{yr}^{-1} \text { for the HIPPO period and } 67 \mathrm{Gg} \mathrm{yr}^{-1} \text { for the ATom period. } \\
\text { The } 20 \mathrm{Gg} \mathrm{yr}^{-1} \text { decrease was imposed over temperate western } \\
\text { Asia. }\end{array}$ \\
\hline 23 & $\begin{array}{l}\text { Flask }+ \text { in situ } \\
\text { measurements }\end{array}$ & Background 2 & $\begin{array}{l}\text { Population-density-based priors with global emissions of } 87 \mathrm{Gg} \\
\mathrm{yr}^{-1} \text { for the HIPPO period and } 67 \mathrm{Gg} \mathrm{yr}^{-1} \text { for the ATom period. } \\
\text { The } 20 \mathrm{Gg} \mathrm{yr}^{-1} \text { decrease was imposed over tropical Asia. }\end{array}$ \\
\hline
\end{tabular}

Notes:

a. With this background, the inversion-derived global emissions would be consistent with those estimated from a 3-box model and an atmospheric lifetime of 52 years

b. With this background, the inversion-derived global emissions were consistent with those estimated from a 3-box model and a lifetime of 54 - 56 years 
Table S2. Uncertainty reduction in percent between the prior and posterior emission estimates in the flask-only inversions (Inversion ID = 1-2 in Table S1) for HIPPO and ATom periods.

Nov 2009 - Sep 2011

Regions prior $=\quad$ prior $=\quad$ prior $=\quad$ prior $=$ population_67 population_40 population_67 population_40

\begin{tabular}{ccccc}
\hline Global and continents & & & & \\
Global & 54 & 69 & 63 & 76 \\
North America & 63 & 75 & 67 & 77 \\
South America & 13 & 26 & 33 & 47 \\
Africa & 3 & 13 & 20 & 36 \\
Asia & 56 & 74 & 64 & 78 \\
Europe & 21 & 41 & 44 & 60 \\
Australia & 4 & 14 & 3 & 13 \\
& & & & 32 \\
Asian subregions & 6 & 28 & 11 & 77 \\
Boreal Asia & 56 & 46 & 68 & 56 \\
Temperate East Asia & 26 & 58 & 39 & 64 \\
Temperate West Asia & 37 & & 47 & \\
Tropical Asia & & & & \\
\hline
\end{tabular}



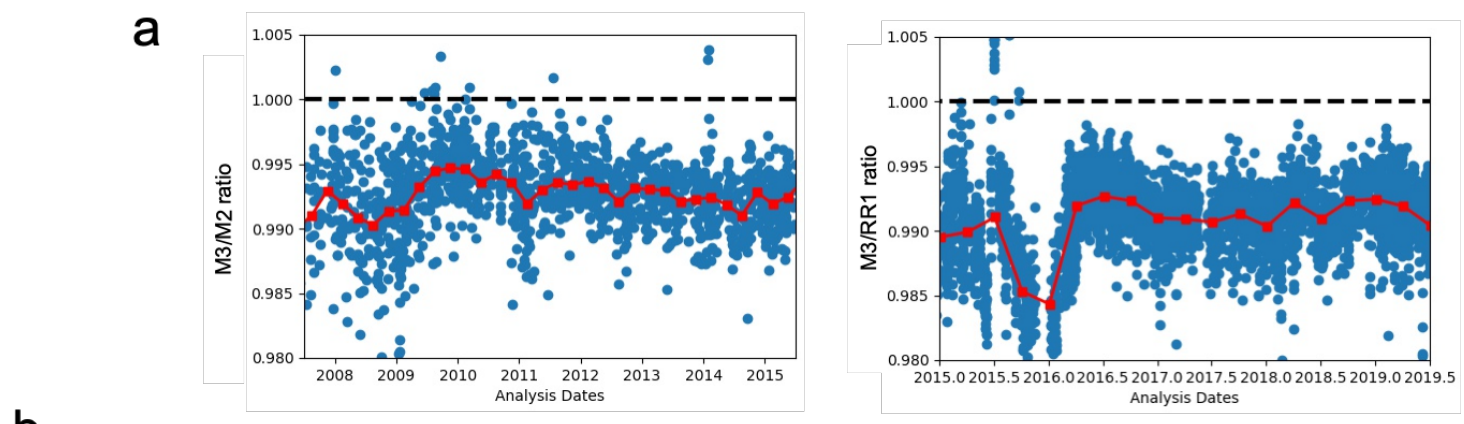

b
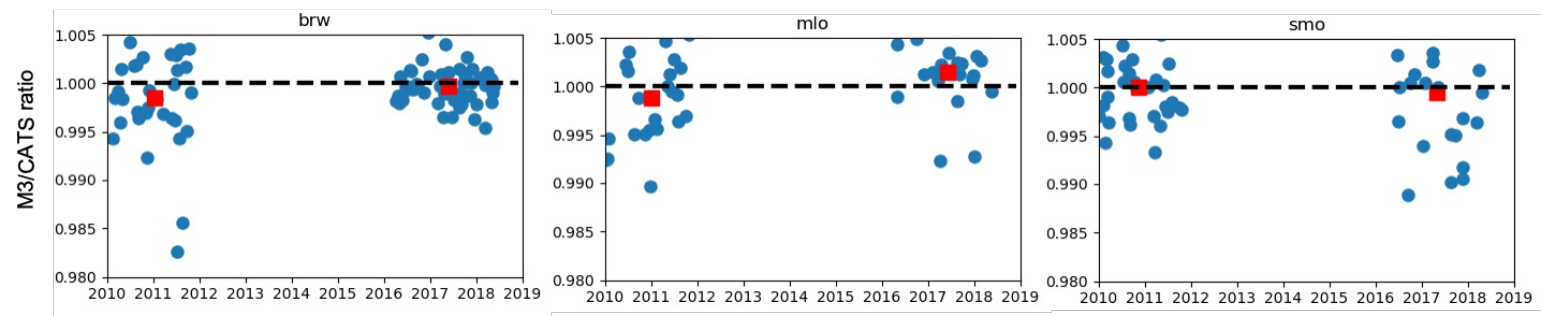

Fig. S1. (a) Comparison of CFC-11 mole fractions ratios measured by three gas chromatograph and mass spectrometry (GCMS) instruments, named "M3", "M2", and "PR1" for the same flaskair samples. Blue symbols denote the measured raw mole fraction ratios between M3 and M2 (left) and between M3 and PR1 (right). Red symbols indicate their three-month median ratios, which were used to improve consistency between measurements on these different instruments (see main text). (b) CFC-11 mole fraction ratios between flask-air samples analyzed by the M3 GCMS instrument and in situ sampling that was collected within \pm 2 hours of the flask-air samples and analyzed by in situ Electron Capture Detection instruments at three surface sites: Barrow, Alaska, United States (BRW), Mauna Loa, Hawaii, United States (MLO), and Tutuila, American Samoa (SMO). Red squares indicate the median scaling factors for the HIPPO and ATom periods, which were used to improve the measurement consistency (see main text). 

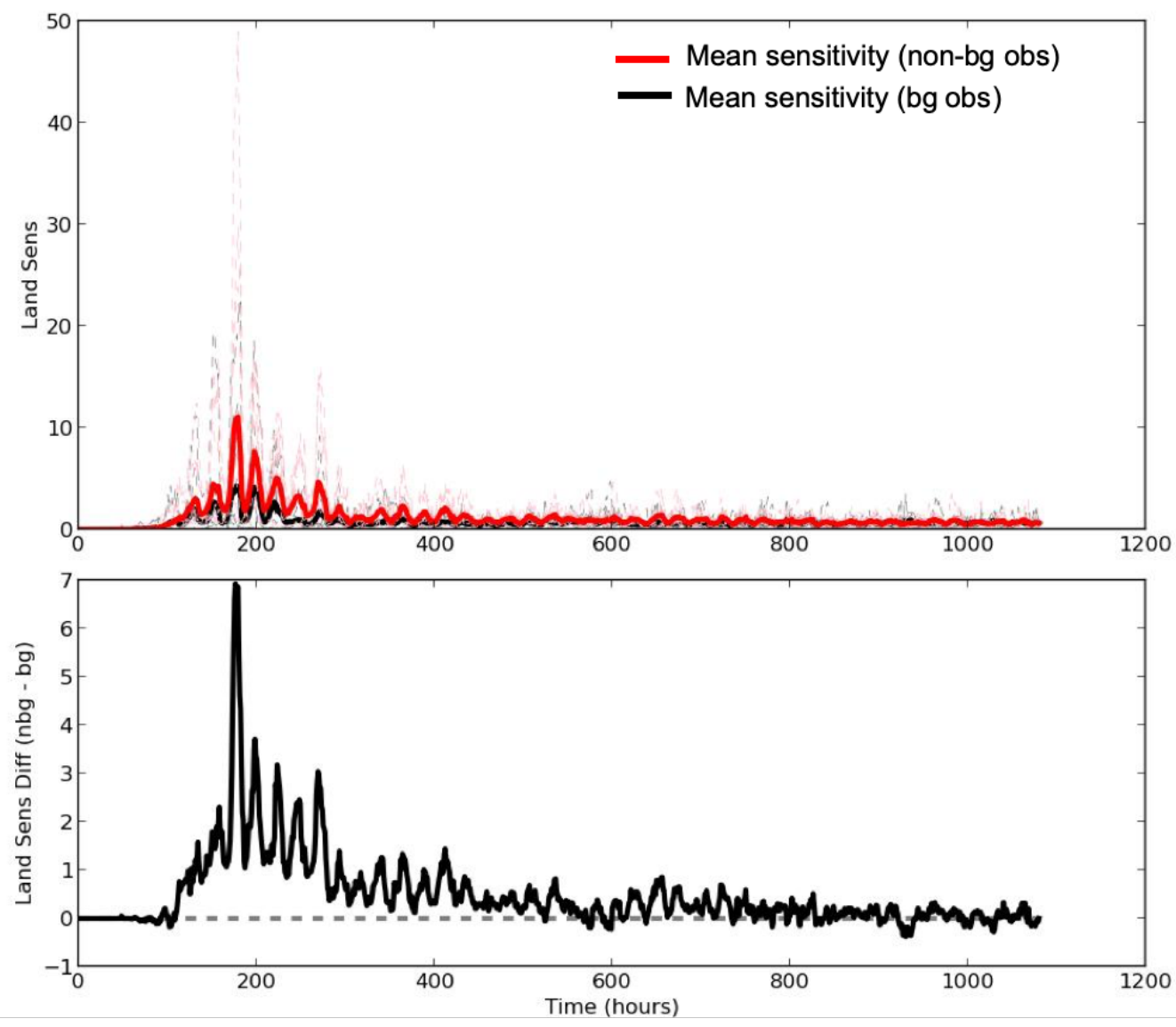

Fig. S2. The upper panel shows the hourly footprint sensitivity in ppt (pmol m $\left.\mathrm{m}^{-2} \mathrm{~s}^{-1}\right)^{-1}$ summed from land grid cells with above zero population for observations with mole fractions below the $50 \%$ th percentile (black) and above the $50 \%$ th percentile (red), collected from the $30-60^{\circ} \mathrm{N}$ at 500 - 750 hpa over the Pacific Ocean Basin from ATom-2. Thin dashed lines represent the summed footprint for individual measurements, whereas the solid lines indicate the mean summed footprints from background and non-background observations. The lower panel indicates the difference between the red and black solid lines shown in the upper panel. 

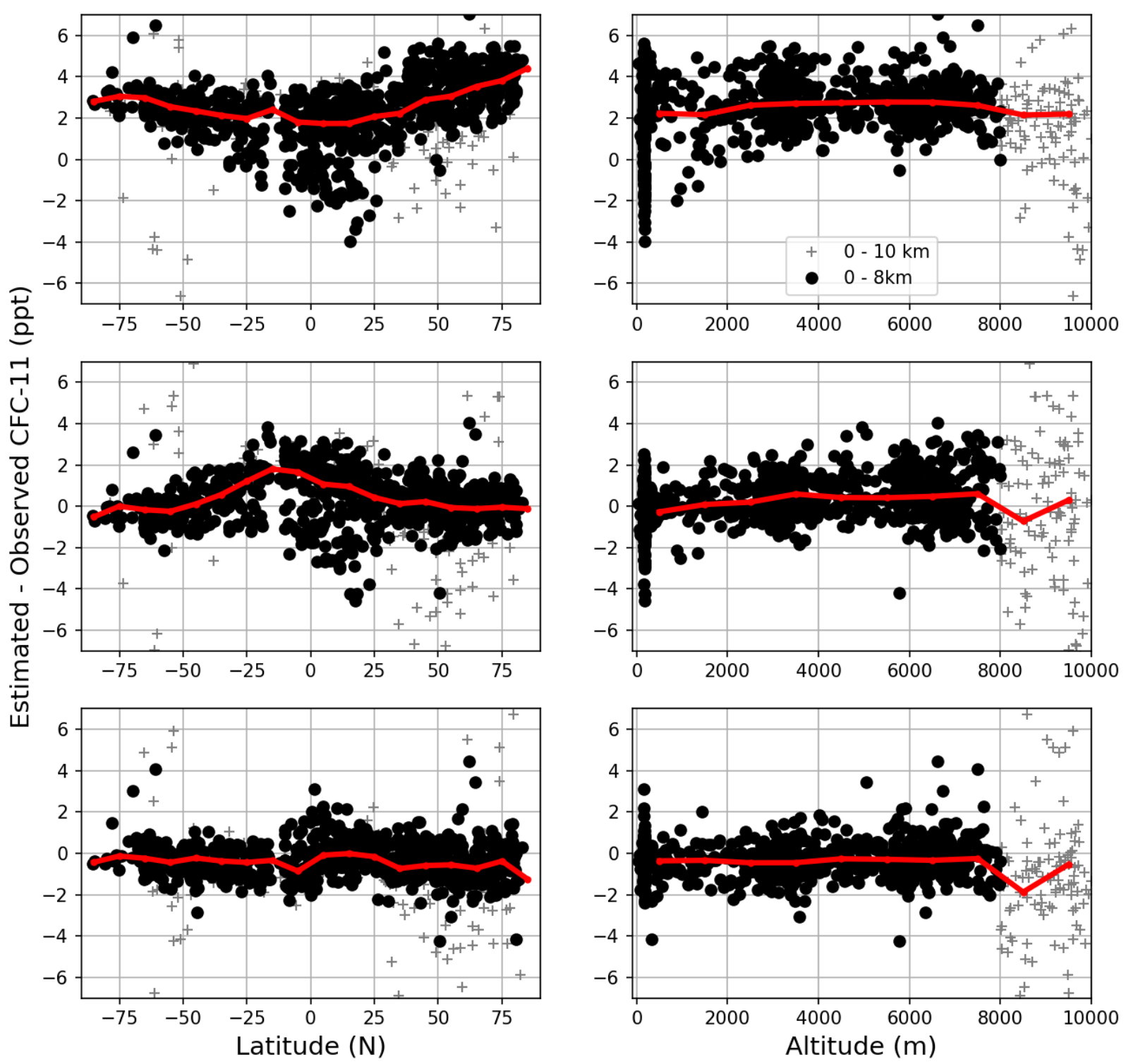

Fig. S3. Residuals of the estimated and observed CFC-11 mole fractions for ATom $1-4$ campaigns, as a function of latitude (left panels) or altitude (right panels). (Upper panels) Estimated CFC-11 mole fractions were derived using the 4D mole fraction field from the WACCM simulation (see text). (Middle panels) Estimated CFC-11 mole fractions were derived using the WACCM 4D mole fraction field that was scaled to match the surface CFC-11 mole fractions observed in the NOAA global surface flask sampling network. (Lower panels) Estimated CFC-11 mole fractions were derived using a constructed $4 \mathrm{D}$ empirical background field. Black circles indicate measurements made below $8 \mathrm{~km}$, whereas black crosses indicate measurements above 8 $\mathrm{km}$. Red solid lines indicate mean biases calculated for bins of 10 degrees in latitudes (left panels) or $1 \mathrm{~km}$ of altitude (right panels). 
HIPPO-3

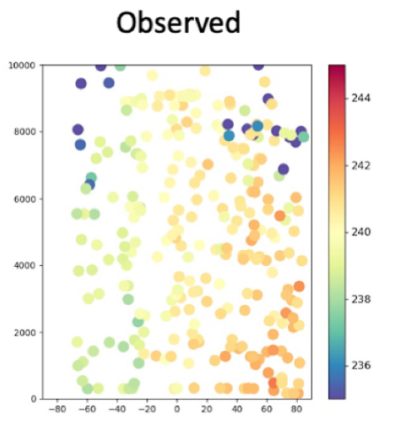

Estimated Bg Atm

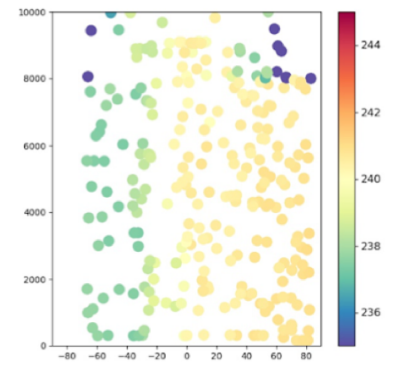

ATom-3

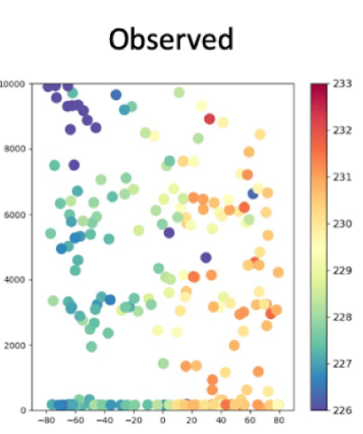

Estimated Bg Atm

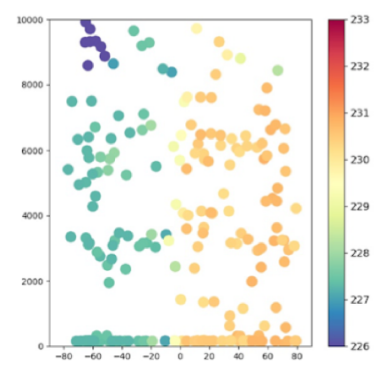

Fig. S4. Comparison of observed CFC-11 mole fractions and estimated background CFC-11 mole fractions (in ppt) for HIPPO-3 and ATom-3 campaigns using the 4D empirical background field.

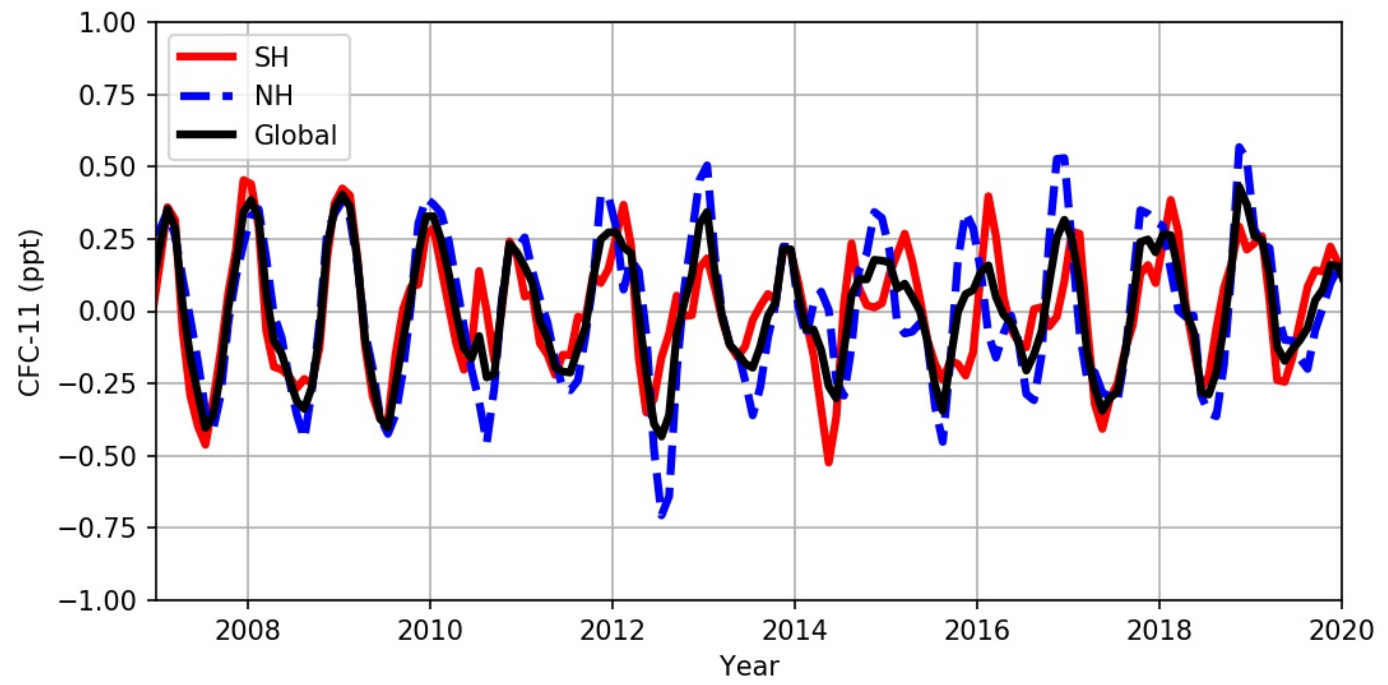

Fig. S5. The seasonal cycle of global and hemispheric mean CFC-11 mole fractions. Data for this calculation is from ftp://aftp.cmdl.noaa.gov/hats/cfcs/cfc11/combined/. The seasonal cycle was calculated based on the global and hemispheric mean CFC-11 mole fractions subtracted by their 12 month running means. 

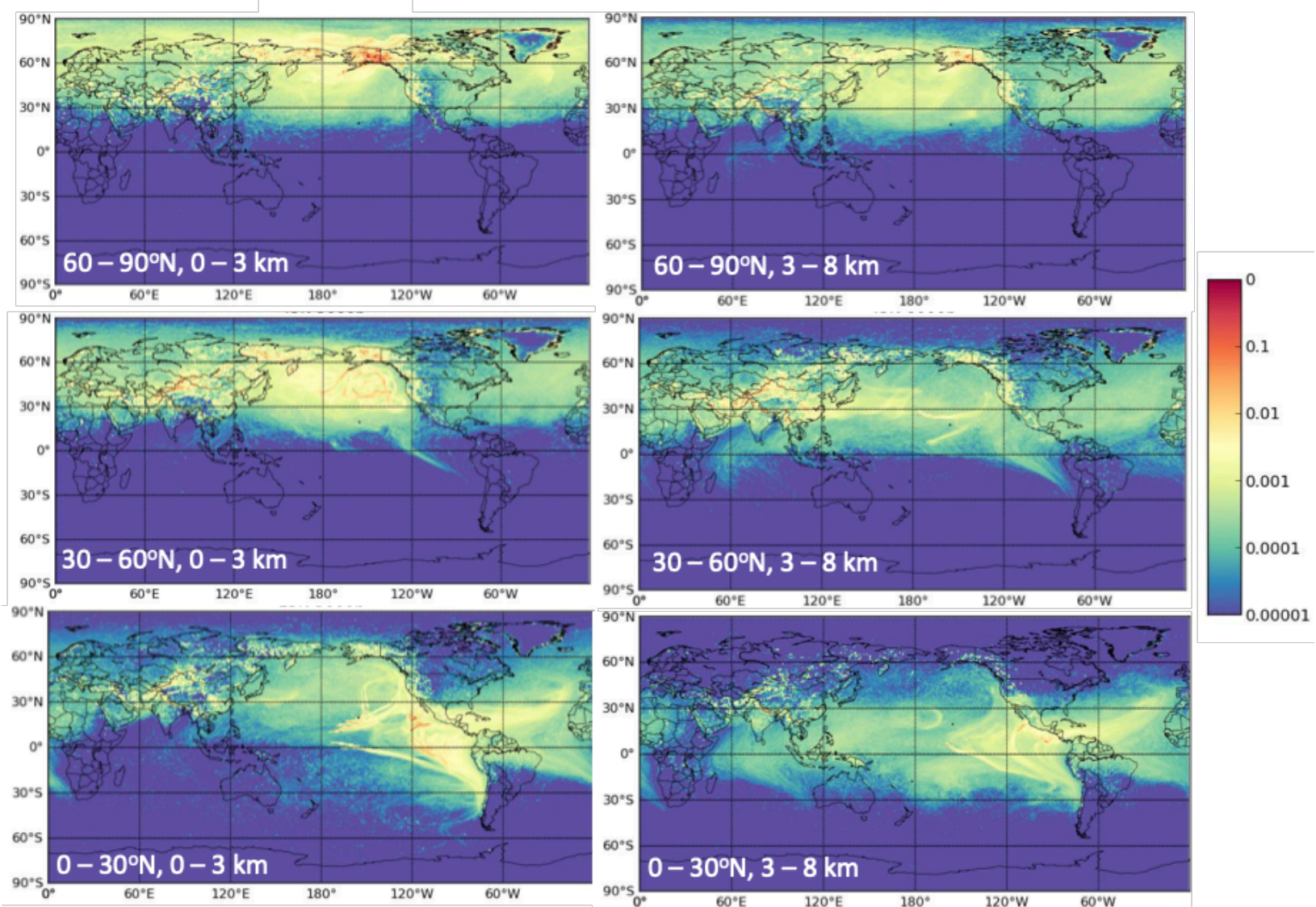

Fig. S6. Average sensitivity of ATom-1 and ATom-2 whole-air flask samples collected between 0 and $8 \mathrm{~km}$ to upwind emissions. The observations were divided into 6 categories every $30^{\circ}$ in latitude and between $0-3 \mathrm{~km}$ and $3-8 \mathrm{~km}$. 